\title{
Quantifying capital goods for waste landfilling
}

Brogaard, Line Kai-Sørensen; Stentsøe, Steen; Willumsen, Hans Christian; Christensen, Thomas Højlund

Published in:

Waste Management and Research

Link to article, DOI:

$10.1177 / 0734242 X 13482032$

Publication date:

2013

Document Version

Peer reviewed version

Link back to DTU Orbit

Citation (APA):

Brogaard, L. K-S., Stentsøe, S., Willumsen, H. C., \& Christensen, T. H. (2013). Quantifying capital goods for waste landfilling. Waste Management and Research, 31(6), 585-598.

https://doi.org/10.1177/0734242X13482032

\section{General rights}

Copyright and moral rights for the publications made accessible in the public portal are retained by the authors and/or other copyright owners and it is a condition of accessing publications that users recognise and abide by the legal requirements associated with these rights.

- Users may download and print one copy of any publication from the public portal for the purpose of private study or research.

- You may not further distribute the material or use it for any profit-making activity or commercial gain

- You may freely distribute the URL identifying the publication in the public portal

If you believe that this document breaches copyright please contact us providing details, and we will remove access to the work immediately and investigate your claim. 


\title{
Quantifying capital goods for waste landfilling
}

\author{
Brogaard $^{1}$, L.K., Stentsøe ${ }^{2}$, S.,Willumsen ${ }^{3}$, H.C. \& Christensen ${ }^{1}$, T.H. \\ ${ }^{1}$ Department of Environmental Engineering \\ Technical University of Denmark \\ 2800 Kongens Lyngby, Denmark \\ ${ }^{2} \mathrm{COWI}$ \\ Parallelvej 2 \\ 2800 Kongens Lyngby, Denmark \\ ${ }^{3}$ LFG Consult \\ Houlkjarshojen 9, \\ 8800 Viborg, Denmark \\ * Corresponding author \\ Department of Environmental Engineering \\ Building 115 \\ Technical University of Denmark \\ 2800 Kongens Lyngby, Denmark \\ Phone: +4545251488 \\ E-mail:1ksb@env.dtu.dk
}

NOTE: this is the author's version of a work that was accepted for publication in journal of Waste Management and Research. Changes resulting from the publishing process, such as peer review, editing, corrections, structural formatting, and other quality control mechanisms may not be reflected in this document. Minor changes may have been made to this manuscript since it was accepted for publication. A definitive version is published in Waste Management and Research, Vol. 31, No. 6, 2013, p. 585-598., doi: 10.1177/0734242X13482032 


\begin{abstract}
Materials and energy used for construction of a hill type landfill of 4 million $\mathrm{m}^{3}$ were quantified in detail. The landfill is engineered with a liner and leachate collections system as well as a gas collection and control system. Gravel and clay were the most common materials used amounting to approximately $260 \mathrm{~kg}$ per tonne of waste landfilled. The environmental burdens from the extraction and manufacturing of the materials used in the landfill as well as from the construction of the landfill were modelled as potential environmental impacts. For example, the potential impact on Global Warming was $2.5 \mathrm{~kg} \mathrm{CO}_{2}$-equivalents or 0.32 milli Person Equivalents (mPE) per tonne of waste. The potential impacts from the use of materials and construction of the landfill are low to insignificant compared to data reported in the literature on impact potentials of landfills in operation. The construction of the landfill is only a significant contributor to the impact of Resource Depletion due to the high use of gravel and steel.
\end{abstract}

Keywords: Landfilling, capital goods, waste, Environmental Impact Assessment (EIA). 


\section{Introduction}

The environmental impacts from waste management systems have been assessed often during the last two decades by life cycle assessment (LCA). The assessments assume a "zero burden" upper boundary for the waste, since the materials constituting the waste were produced and used for a purpose, not for becoming waste. The assessments focus on the operation of the waste management technologies while capital goods and infrastructure are seldom included. Capital goods is a common term for the materials and energy used to establish the facility prior to the operation. Our knowledge about the importance of capital goods in waste management is rudimentary. Cleary (2009) showed in a review of 20 peer-reviewed papers on LCAs on waste management systems that only 2 stated they included capital goods, 7 specifically excluded the emissions from the production of capital goods and infrastructure, while the remaining 11 did not mention whether capital goods were included or not.

Landfills are included in most waste management systems and are large constructions (Bagchi 1994, Ecobalance 1999, Christensen 2011), but only a few studies have addressed the environmental impacts from the materials and energy used (capital goods) in construction of landfills (Frischknecht et al. 2007, Ecobalance 1999 and Menard et al. 2004).

Menard et al. (2004) compared the capital goods and operational performance of two landfill technologies: an engineered landfill and a bioreactor landfill. Menard et al. (2004) describe the engineered landfill with no utilization of landfill gas and two scenarios for the bioreactor landfill; one with utilization of landfill gas to electricity and another with utilization for heat. They concluded that the two bioreactor scenarios had lower environmental impacts than the engineered landfill due to the utilization of the landfill gas and the fact that the engineered landfill had lower efficiency of the gas extraction and thereby higher emissions to the atmosphere. The amount of materials and energy used in construction of the landfill were not significantly different for the two technologies (Menard et al. 2004). The quantification of materials for constructing the landfills determined by Menard et al. (2004) are shown later in this paper for comparison with the current study.

The study from Frischknecht et al. (2007) was based on data from Ecoinvent (Ecoinvent 2012) and did not present the amounts of materials needed for construction of landfills, but showed the impact assessment. For the capital goods related to waste management they found that the potential impacts depend on the type of waste included in the assessment. For the sanitary landfill and residual materials landfill the main impacts $(>90 \%)$ were found to be on Resources/Mineral Extraction. For the categories: Land Use, Non-Renewable Cumulative Energy Demand, Climate Change, Acidification and Terrestrial Ecotoxicity the impacts categories were significant $(10 \%-90 \%)$. The general conclusion was that Land Use and Resources/Mineral Extraction were the main factors related to the capital goods. The data concerning capital goods used by Frischknecht et al. (2007) are not presented within this paper since they were not presented in the paper by Frischknecht et al. (2007).

The report from Ecobalance (1999) is based on data from 100 landfills reporting their use of materials, landfill capacity, type of liner system and gas collection systems. The report presents average numbers for the landfills and constitutes an LCI of a modern municipal solid waste landfill. Some of the results from the LCA of the full life time of the landfill are summarized by Camobreco et al., (1999). The data is presented later in this paper. 


\section{Approach and method}

The goal of this study is to quantify the use of materials and energy for constructing a modern landfill. Only the extraction and production of materials and the construction of the landfill are assessed in this paper and thereby not the use and disposal phase of the landfill, see Figure 1. Maintenance and spare parts during the life time of the landfill are included, but the worn out parts from maintenance or substitution are not considered disposed until the disposal phase of the capital goods (above ground) of the landfill, which is not included in this paper. The inventory data were furthermore used to model the environmental profile of the capital goods in order to assess their significance.

\section{System boundary}

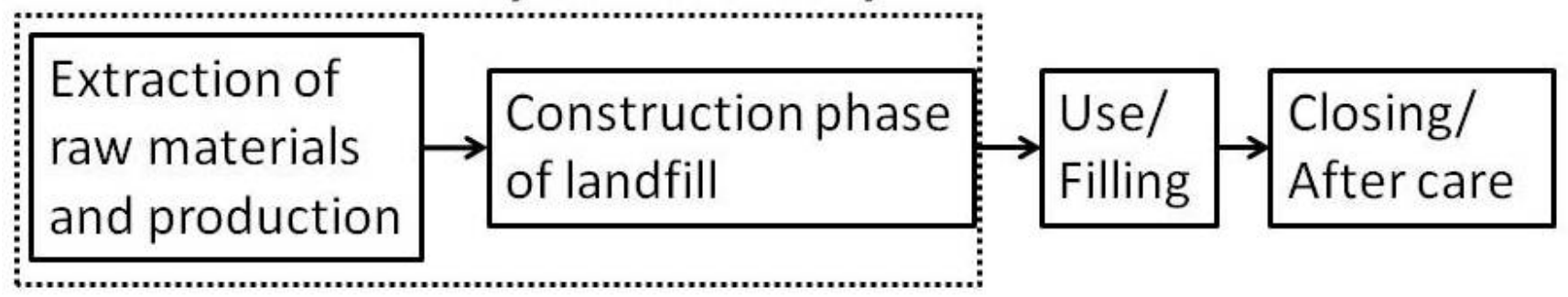

Figure 1: System boundary for the environmental impact assessment of capital goods. All energy and transportation are included.

\subsection{Inventory data}

The data on material use and landfill construction were defined for a hypothetical hill type landfill with a capacity of approximately 4 million $\mathrm{m}^{3}$ constructed from scratch with an appropriate liner and leachate collection systems as well as a gas collection and utilization system. All information is based on design reports for a range of landfills made by COWI or LFG Consult - two Danish companies involved for decades in landfill design and construction.

The inventory is built in such a way that the data easily can be extrapolated to present a landfill with slightly different features or a different capacity. Adjustments to different landfill depths and wastes density can easily be made. Similarly the inventory can be modified to also cover landfills located in a pit or canyon. The hill type landfill is assumed constructed on a bare field with some soil excavated (see details later), while for a pit or canyon landfill, excavation of soil before construction is not needed. The use of materials for the liner system was estimated to be $5 \%$ higher for a pit or canyon landfill than for the hill type landfill with the same filling capacity due to the topographical difference. The energy consumption for constructing a landfill in a pit or canyon may be higher due to more energy needed for machinery operating on the slopes. The extra amount of energy needed in comparison to the hill type landfill is however not specified.

\subsection{Environmental profile}

The landfill inventory data were subject to an environmental assessment in order to estimate the significance of the capital goods.

Data on the environmental profile of the materials and energy used in the construction of the landfill were in most cases obtained from the Swiss database Ecoinvent 2.2 (Ecoinvent 2011). Some data were from Environmental Product Declarations from companies producing the used products (e.g. pumps (Flygt 2012)). All information about energy consumption by machinery during construction was from 
Caterpillar (2009) and Stripple (2001). Data was taken from published reports and documents where it was possible. However, in a few cases data was obtained by personal communication with people from companies producing materials and components for landfills.

All concrete was modelled as not being reinforced because of limited life cycle inventory (LCI) data. The steel used for reinforcement was included in all cases but only as the production of steel, due to lack of data for reinforced concrete. The steel used for reinforcement is different from the steel used for pumps, containers, fence and gates. These two types of steel are also different with respect to their environmental profile.

The gravel roads were modelled as excavation of gravel at pit, transportation of gravel from pit to the site, and distribution of the gravel on site by a dumper. Asphalt roads were included using LCI data from the Ecoinvent database (Ecoinvent 2011).

Diesel consumption at site was modelled as combusted in a EURO3 type truck since it was not possible to model it as used in the specific types of machinery (e.g. dumper) used at the landfill site. The actual emissions are likely to be larger.

The environmental impact assessment was made by means of Simapro 7.2 developed by PRé consultants (PRé 2011). This software is user-friendly and was chosen because it contains comprehensive databases from among others the Ecoinvent 2.2 (Ecoinvent 2011).

Emissions from the production of materials and energy were aggregated, characterised and normalised into the impact categories presented in Table 1. From the environmental design of industrial products EDIP methodology (Wenzel et al., 1997) the non toxic categories chosen were: Global Warming, Ozone Depletion, Acidification, Terrestrial Eutrophication, Aquatic Eutrophication (N- and Pequivalents), Photochemical Ozone Formation related to the impacts on vegetation and human health and Resource Depletion. The latest updated normalisation references for 2004 were used (Laurent et al. 2011a).The toxicity related categories (Human Toxicity, Cancer and Non-Cancer Related and Ecotoxicity) were defined by the USEtox methodology (USEtox 2009). The normalisation references for the USEtox methodology were determined by Laurent et al. (2011b) see Table 1. 
Table 1: Environmental impact categories and normalisation references used for the assessment (Laurent et al. 2011a, Laurent et al. 2011b). UES: Unprotected Eco-System. CTU: Comparative Toxic Unit, e: Ecotoxicity, h: human.

\begin{tabular}{|c|c|c|c|}
\hline Impact categories & $\begin{array}{r}\text { Geographical } \\
\text { scope }\end{array}$ & $\begin{array}{r}\text { Normalization } \\
\text { references }\end{array}$ & Unit \\
\hline \multicolumn{4}{|l|}{ EDIP } \\
\hline Global Warming & World & $7.73 \mathrm{E}+03$ & {$\left[\mathrm{~kg}-\mathrm{CO}_{2}\right.$-eq/person/year $]$} \\
\hline Ozone Depletion & World & $2.05 \mathrm{E}-02$ & [kg-CFC-11-eq/person/year] \\
\hline Acidification & Europe & $5.48 \mathrm{E}+01$ & {$\left[\mathrm{~kg}-\mathrm{SO}_{2-\text { eq }} /\right.$ person/year $]$} \\
\hline Terrestrial Eutrophication & Europe & $1.37 \mathrm{E}+03$ & {$\left[\mathrm{~m}^{2}\right.$ UES/person/year $]$} \\
\hline Aquatic Eutrophication (N-equivalents) & Europe & $8.32 \mathrm{E}+00$ & [kg N-eq/person/year] \\
\hline Aquatic Eutrophication (P-equivalents) & Europe & $2.82 \mathrm{E}-01$ & [kg P-eq/person/year] \\
\hline Photochemical Ozone Formation - impacts on vegetation & Europe & $5.97 \mathrm{E}+04$ & {$\left[\mathrm{~m}^{2} . \mathrm{ppm} \cdot \mathrm{hr} / \mathrm{person} / \mathrm{year}\right]$} \\
\hline Photochemical Ozone Formation - impacts on human health & Europe & $2.84 \mathrm{E}+00$ & {$\left[\mathrm{~m}^{2} . \mathrm{ppm} \cdot \mathrm{hr} /\right.$ person/year $]$} \\
\hline Resource Depletion & World & $8.17 \mathrm{E}-01$ & $\begin{array}{r}\text { [Person } \\
\text { reserves/person/year }] \\
\end{array}$ \\
\hline \multicolumn{4}{|l|}{ USEtox } \\
\hline Human Toxicity, cancer & Europe & $3.25 \mathrm{E}-05$ & [CTUh/person/year] \\
\hline Human Toxicity, non-cancer & Europe & $8.14 \mathrm{E}-04$ & [CTUh/person/year] \\
\hline Ecotoxicity & Europe & $5.06 \mathrm{E}+03$ & [CTUe/person/year] \\
\hline
\end{tabular}

\section{Presentation of a hill type landfill}

The landfill described in this paper is a constructed example of a hill type landfill. The landfill covers $300000 \mathrm{~m}^{2}$ and contains 30 cells with a total capacity of approximately 4 million $\mathrm{m}^{3}\left(4075776 \mathrm{~m}^{3}\right)$.

The layout of the landfill area will always depend on the available space provided for constructing a landfill. In this paper the landfill is assumed to be rectangular to ease the calculation of materials needed. The collected data can easily be applied to other shapes of landfills. The quantification of materials and energy are presented in Table 2 and described in the following section. The concept of the landfill construction is shown in Figure 2. 
Table 2: Materials and energy used for the construction of a hill type landfill of 4 million $\mathrm{m}^{3}$.

\begin{tabular}{|c|c|c|c|c|c|c|c|c|}
\hline & \multicolumn{2}{|l|}{ Energy } & \multicolumn{6}{|c|}{ Materials } \\
\hline & 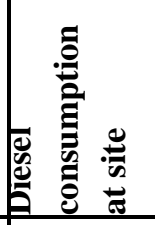 & 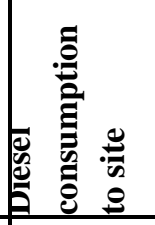 & 䒕 & 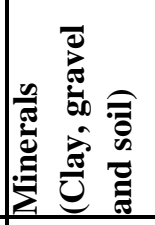 & 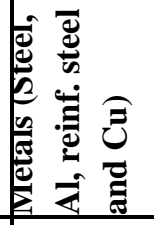 & 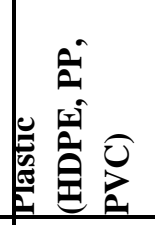 & $\frac{\frac{7}{\pi}}{\frac{\pi}{2}}$ & $\frac{\mathscr{e}}{\tilde{0}}$ \\
\hline Description & {$[1]$} & {$[1]$} & {$[\mathrm{t}]$} & {$[\mathrm{t}]$} & {$[\mathrm{t}]$} & {$[\mathrm{t}]$} & {$\left[\mathrm{m}^{2}\right]$} & [m] \\
\hline Total amount of materials & 436000 & 402000 & 3500 & 1494000 & 500 & 800 & 6600 & 4000 \\
\hline \multicolumn{9}{|l|}{ Preparing earthwork } \\
\hline Clear cutting of bushes, trees ect. & 24000 & 0 & 0 & 0 & 0 & 0 & 0 & 0 \\
\hline $\begin{array}{l}\text { Topsoil stripping and transport to } \\
\text { deposit at site }\end{array}$ & 22600 & 0 & 0 & 0 & 0 & 0 & 0 & 0 \\
\hline $\begin{array}{l}\text { Soil for top cover, stripping and } \\
\text { transport to deposit at site }\end{array}$ & 87500 & 0 & 0 & 0 & 0 & 0 & 0 & 0 \\
\hline $\begin{array}{l}\text { Excavation of soil and establishment } \\
\text { of embankments etc. }\end{array}$ & 22400 & 0 & 0 & 105200 & 0 & 0 & 0 & 0 \\
\hline \multicolumn{9}{|l|}{ Membrane system } \\
\hline $\begin{array}{l}\text { Geological barrier (clay), delivered } \\
\text { and built into the membrane system }\end{array}$ & 45550 & 128300 & 0 & 285000 & 0 & 0 & 0 & 0 \\
\hline $\begin{array}{l}\text { Plastic membrane, HDPE, } \mathrm{t}=1.5 \\
\mathrm{~mm} \text {, delivered and built into the } \\
\text { membrane system }\end{array}$ & 0 & 320 & 0 & 0 & 0 & 420 & 0 & 0 \\
\hline \multicolumn{9}{|l|}{ Leachate system } \\
\hline $\begin{array}{l}\text { Drainage gravel, } 0-4 \mathrm{~mm}, \mathrm{t}=0.5 \mathrm{~m} \text {, } \\
\text { delivered and built into the leachate } \\
\text { system }\end{array}$ & 16500 & 128300 & 0 & 285000 & 0 & 0 & 0 & 0 \\
\hline $\begin{array}{l}\text { Drainage pipes, } \varnothing 110 \text { HDPE Pn10, } \\
\text { delivered and built into the leachate } \\
\text { system }\end{array}$ & 100 & 70 & 0 & 0 & 0 & 90 & 0 & 0 \\
\hline $\begin{array}{l}\text { Stone fascines, } 4-8 \mathrm{~mm} \text {, delivered } \\
\text { and built into the leachate system }\end{array}$ & 800 & 6500 & 0 & 14500 & 0 & 0 & 0 & 0 \\
\hline $\begin{array}{l}\text { Concrete plate for protection at } \\
\text { outlet }\end{array}$ & 0 & 30 & 40 & 0 & 2 & 0 & 0 & 0 \\
\hline $\begin{array}{l}\text { Geo-textile under stone fascines, } \\
\mathrm{t}=1.5 \mathrm{~mm} \text {, HDPE }\end{array}$ & 0 & 17 & 0 & 0 & 0 & 20 & 0 & 0 \\
\hline \multicolumn{9}{|l|}{ Collection and inspection wells } \\
\hline $\begin{array}{l}\text { Concrete wells, } \mathrm{h}=2.5 \mathrm{~m} \text {, delivered } \\
\text { and built }\end{array}$ & 0 & 1600 & 1020 & 0 & 50 & 0 & 0 & 0 \\
\hline \multicolumn{9}{|l|}{$\begin{array}{l}\text { Pipes for leachate transport and } \\
\text { wells }\end{array}$} \\
\hline $\begin{array}{l}\text { Pipes } \varnothing 250 \mathrm{~mm} \text { HDPE, Pn } 10 \text {, } \\
\text { transport pipes, delivered and built } \\
\text { into the leachate system }\end{array}$ & 7500 & 70 & 0 & 0 & 0 & 100 & 0 & 0 \\
\hline $\begin{array}{l}\text { Wells for cleaning transport pipes, } \\
\varnothing 315 \mathrm{~mm} \text { HDPE, delivered and } \\
\text { built into the leachate system }\end{array}$ & 0 & 0 & 0 & 0 & 0 & 3 & 0 & 0 \\
\hline \multicolumn{9}{|l|}{ Pumping station } \\
\hline $\begin{array}{l}\text { Concrete wells/structure, delivered } \\
\text { and built into the leachate system }\end{array}$ & 0 & 140 & 170 & 0 & 10 & 0 & 0 & 0 \\
\hline
\end{tabular}




\begin{tabular}{|c|c|c|c|c|c|c|c|c|}
\hline Pipe work, fittings and valves & 0 & 0 & 0 & 0 & 0 & 0.09 & 0 & 0 \\
\hline Pumps & 0 & 1 & 0 & 0 & 0.55 & 0 & 0 & 0 \\
\hline $\begin{array}{l}\text { Electrical installations (breaker } \\
\text { panel, SRO-system) }\end{array}$ & 0 & 0 & 0 & 0 & 0.04 & 0 & 0 & 80 \\
\hline Various stairs and other metal parts & 0 & 0 & 0 & 0 & 0.01 & 0 & 0 & 0 \\
\hline \multicolumn{9}{|l|}{ Leachate tank } \\
\hline $\begin{array}{l}\text { Concrete tank, Ø30 m, h=3.0 m, } \\
\text { delivered and installed }\end{array}$ & 0 & 3300 & 2100 & 0 & 100 & 0 & 0 & 0 \\
\hline $\begin{array}{l}\text { Electrical installations (SRO- } \\
\text { system) }\end{array}$ & 0 & 0 & 0 & 0 & 0.13 & 0 & 0 & 100 \\
\hline \multicolumn{9}{|l|}{ Surface water systems } \\
\hline $\begin{array}{l}\text { Excavating intercepting ditches, } \\
\mathrm{d}=1.0 \mathrm{~m}\end{array}$ & 800 & 0 & 0 & 0 & 0 & 0 & 0 & 0 \\
\hline Collection reservoir & 0 & 0 & 0 & 0 & 0 & 0 & 0 & 0 \\
\hline \multicolumn{9}{|l|}{ Fence and gates } \\
\hline $\begin{array}{l}\text { Fence } \mathrm{h}=2.2 \mathrm{~m} \text {, delivered and } \\
\text { installed }\end{array}$ & 0 & 170 & 0 & 0 & 110 & 0 & 0 & 0 \\
\hline $\begin{array}{l}\text { Gates, } 2 * 3 \mathrm{~m} \text {, delivered and } \\
\text { installed }\end{array}$ & 0 & 10 & 0 & 0 & 1 & 0 & 0 & 0 \\
\hline \multicolumn{9}{|l|}{ Monitoring wells } \\
\hline $\begin{array}{l}\text { Establishment of } 6 \text { monitoring } \\
\text { wells, } d=15 \mathrm{~m}\end{array}$ & 0 & 500 & 10 & 0 & 40 & 180 & 0 & 0 \\
\hline \multicolumn{9}{|l|}{ Reception area } \\
\hline $\begin{array}{l}\text { Weighbridges, delivered and } \\
\text { installed }\end{array}$ & 0 & 150 & 100 & 0 & 0.41 & 0 & 0 & 0 \\
\hline Office building & 0 & 0 & 0 & 0 & 0 & 0 & 0 & 0 \\
\hline Truck wash building & 0 & 0 & 0 & 0 & 0 & 0 & 0 & 0 \\
\hline Garage building & 0 & 0 & 0 & 0 & 0 & 0 & 0 & 0 \\
\hline Access road - asphalt, $b=6 \mathrm{~m}$ & 0 & 0 & 0 & 0 & 0 & 0 & 6600 & 0 \\
\hline Interim roads - gravel, $\mathrm{b}=6 \mathrm{~m}$ & 6500 & 3950 & 0 & 8800 & 0 & 0 & 0 & 0 \\
\hline Lighting & 0 & 120 & 100 & 0 & 10 & 0 & 0 & 0 \\
\hline Power supply and data cables & 0 & 1 & 0 & 0 & 0 & 0 & 0 & 3800 \\
\hline \multicolumn{9}{|l|}{ Top cover and gas collection } \\
\hline Planing of waste surface & 20900 & 0 & 0 & 0 & 0 & 0 & 0 & 0 \\
\hline $\begin{array}{l}\text { Gas collection pipes and vertical gas } \\
\text { drainage pipes, HDPE and PVC, } \\
\text { delivered and installed }\end{array}$ & 20 & 10 & 0 & 0 & 0 & 10 & 0 & 0 \\
\hline $\begin{array}{l}\text { Gravel and clay for the closure } \\
\text { around extraction/drain, delivered } \\
\text { and installed }\end{array}$ & 40 & 200 & 0 & 450 & 0 & 0 & 0 & 0 \\
\hline $\begin{array}{l}\text { Gravel layer for gas collection } \\
\mathrm{t}=0.5 \mathrm{~m} \text {, delivered and installed }\end{array}$ & 34800 & 128300 & 0 & 315000 & 0 & 0 & 0 & 0 \\
\hline $\begin{array}{l}\text { HDPE membrane barrier installed } \\
\text { around gas extraction wells to } \\
\text { reduce intake of atmospheric air }\end{array}$ & 0 & 10 & 0 & 0 & 0 & 20 & 0 & 0 \\
\hline $\begin{array}{l}\text { Soil cover }(\mathrm{t}=0.8 \mathrm{~m}) \text { built in from } \\
\text { deposit at site }\end{array}$ & 117100 & 0 & 0 & 408000 & 0 & 0 & 0 & 0 \\
\hline
\end{tabular}




\begin{tabular}{|l|r|r|r|r|r|r|r|r|}
$\begin{array}{l}\text { Top soil }(\mathrm{t}=0.2 \mathrm{~m} \text { ) built in from } \\
\text { deposit at site }\end{array}$ & 29300 & 0 & 0 & 72000 & 0 & 0 & 0 & 0 \\
\hline $\begin{array}{l}\text { Containers with motors and } \\
\text { generators of } 800-1.000 \mathrm{~kW} \\
\text { electricity }\end{array}$ & 0 & 150 & 0 & 0 & 100 & 0 & 0 & 0 \\
\hline $\begin{array}{l}\text { Containers for gas collection pumps } \\
\text { and misc. }\end{array}$ & 0 & 60 & 0 & 0 & 40 & 0 & 0 & 0 \\
\hline Flare & 0 & 0 & 0 & 0 & 2 & 0 & 0 & 0 \\
\hline
\end{tabular}




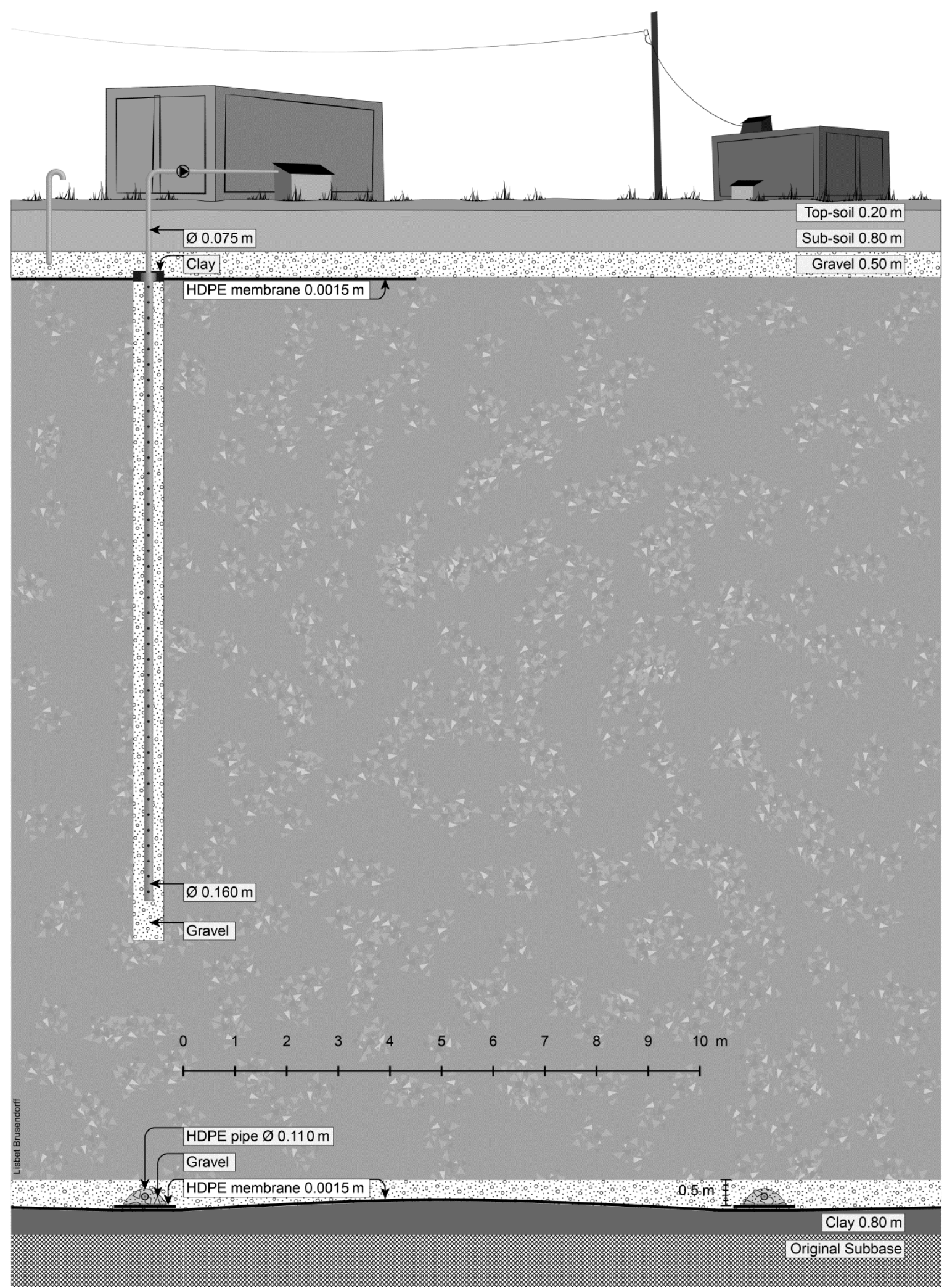

Figure 2: Design of landfill, showing the membrane system, leachate collection and gas collection.

\subsection{Landfill elements}

The construction of the landfill was divided into several construction elements in order to ease the presentation and organize the inventory data.

\section{Transportation}


All transportation at the landfill site was quantified as listed in Table 3. This is based on the amounts of materials needed and the machinery used for handling the materials. Capacities of the machinery (e.g. movement of $\mathrm{m}^{3} / \mathrm{h}$ ) were used together with the fuel consumption per hour to quantify the amount of diesel consumed for the whole construction of the landfill. An efficiency of 50 minutes per hour was used for all machinery at the landfill, but full efficiency was assumed for the truck. See Table 3 for details about the machinery. Materials needed for producing the machinery were not quantified since only the landfill itself is considered in this paper. The machinery could be used elsewhere before and after the use at the landfill and is therefore not quantified here.

Transportation of materials was assumed to take place by a single type of truck with a consumption of diesel of 0.03 litres per tonne and $\mathrm{km}$. This number was calculated from the study by Stripple (2001). However, the diesel consumption for the transport by truck depends on the type, size and driving of the truck and also on the load.

The distance driven with the materials are shown in Table 4. It is assumed that all materials are accessible within a distance of $15-50 \mathrm{~km}$. This may not always be the case for all materials, but since the diesel consumption is linear with distance, adjustments can easily be made to fit specific needs. Transportation of diesel and asphalt was not included. The transportation of soil was only at site $(<1$ $\mathrm{km})$.

Table 3: Machinery used for the construction of a landfill of 4 million $\mathrm{m}^{3}$. The capacity shown is at $100 \%$ efficiency of the machinery (60 minutes per hour).

\begin{tabular}{|l|l|r|r|r|r|}
\hline Machinery & Type & Consumption & Capacity & Unit & Reference \\
\hline & & {$[1 / \mathrm{h}]$} & & & \\
\hline Bulldozer & Caterpillar D8T & 58 & 300 & {$\left[\mathrm{~m}^{3} / \mathrm{h}\right]$} & Caterpillar 2009 \\
\hline Compactor & Dynapac CA 301D, 12t, 6 pass & 18 & 1207 & {$\left[\mathrm{~m}^{2} / \mathrm{h}\right]$} & Stripple 2001 \\
\hline Dumper & Volvo BM A35 & 27.5 & 0.193 & {$\left[1 / \mathrm{m}^{3} \mathrm{~km}\right]$} & Stripple 2001 \\
\hline Excavator & Åkerman EC620, Excv.Cls. 2 & 34 & 430 & {$\left[\mathrm{~m}^{3} / \mathrm{h}\right]$} & Stripple 2001 \\
\hline Frontloader & Volvo BM L180, Excv.Cls. 2 & 35 & 410 & {$\left[\mathrm{~m}^{3} / \mathrm{h}\right]$} & Stripple 2001 \\
\hline Truck/Lorry & Distribution truck, 14 t & - & 0.03 & {$[1 / \mathrm{tkm}]$} & Stripple 2001 \\
\hline
\end{tabular}


Table 4: Transport distances from production of materials and goods to site.

\begin{tabular}{|l|r|}
\hline Materials & From production to site \\
\hline & {$[\mathrm{km}]$} \\
\hline Aluminium & 50 \\
\hline Asphalt & Not included \\
\hline Cables & 50 \\
\hline Clay & 15 \\
\hline Concrete & 50 \\
\hline Copper & 50 \\
\hline Diesel & Not included \\
\hline Gravel & 15 \\
\hline HDPE & 25 \\
\hline PP & 25 \\
\hline PVC & 25 \\
\hline Reinforcement steel & 50 \\
\hline Soil & 50 \\
\hline Steel & On site transportation \\
\hline
\end{tabular}

\section{Preparation of the area}

All plants and trees are cut down during preparation of the area. The energy consumption for cutting and removing the vegetation was quantified to be 0.08 litres of diesel per $\mathrm{m}^{2}$ (ROAD-RES 2005). The top soil $(0-0.2 \mathrm{~m})$ was removed and stored at the landfill site for later use. Also the soil below $(0.2 \mathrm{~m}$ $-1 \mathrm{~m}$ ) was removed and stored for later use. Lowering of the ground water table in the area of the landfill was not considered.

About $60000 \mathrm{~m}^{3}\left(58448 \mathrm{~m}^{3}\right)$ of soil from the site was compacted for the construction of embankments. A bulldozer, a compactor and a dumper were used for preparation of the site. The details about diesel consumptions etc. can be found in Table 3 .

\section{Bottom liner}

The bottom liner consists of two layers: a clay layer of $0.5 \mathrm{~m}$ and on top a plastic membrane of high density polyethylene (HDPE) with a thickness of $0.0015 \mathrm{~m}$ (see Figure 2). The clay is excavated at mine, transported by truck $15 \mathrm{~km}$ to the site, spread with a bulldozer and compacted by a compactor. Watering of the clay liner was not included.

The HDPE membrane was $300000 \mathrm{~m}^{2}$ with a total weight of $423 \mathrm{t}$. It was transported to the site as rolls by truck $(25 \mathrm{~km})$. The HDPE liner was rolled out and welded with a device using electricity from a diesel generator. The energy consumption for rolling out the HDPE liner and welding it was considered insignificant and no quantification was attempted.

\section{Leachate drainage and management}

Gravel for use as a drain layer $(0.5 \mathrm{~m})$ on top of the liner was transported $15 \mathrm{~km}$ to the site by truck and spread on site by a dumper. About $150000 \mathrm{~m}^{3}$ of gravel was used for the drainage layer of the whole landfill. In total 37000 meters of HDPE pipes of $0.110 \mathrm{~m}$ diameter suitable for pressure below 
10 bar were used for draining the leachate. The pipes were transported to the site by truck and distributed on site with a front loader. Only half of the capacity of the front-loader was assumed used for distributing the pipes at site since the pipes have a high volume compared to the weight. Coarse gravel was used around the drainage pipes constituting a trapezium cross-sectional area of $\sim 0.218 \mathrm{~m}^{2}$ being 3 times higher and 3 times wider than the pipe diameter of $0.110 \mathrm{~m}$. Below the coarse gravel a 2 $\mathrm{m}$ wide HDPE geo-textile was used (0.0015 $\mathrm{m}$ thickness). This geotextile was transported to the site by truck for $25 \mathrm{~km}$. At the discharge leachate drainage points from each landfill cell a concrete plate was installed of $2 \mathrm{~m} * 3 \mathrm{~m} * 0.1 \mathrm{~m}$ to protect the outlet. In total 30 discharge points were used in the $300000 \mathrm{~m}^{2}$ large landfill. The concrete plates contained about $5 \%$ of reinforcement steel.

Two leachate collection and inspection wells of concrete were installed in each cell amounting to 60 wells in total for the landfill. The wells contained 5\% steel reinforcement. The lifetime of these wells was estimated to 30 years so maintenance will be necessary. Measuring equipment for flow, electricity and Screen Capture And Data Analysis (SCADA) for the collection and inspection wells were not included.

Transportation pipes (in total $8205 \mathrm{~m}$ ) were installed for the transport of the leachate from the cells to the leachate tank. These pipes were of HDPE with a diameter $0.25 \mathrm{~m}$ and made for a pressure of 10 bar. The diesel consumption used for excavating the soil, laying the pipes, backfilling and compaction of the soil was included in the quantification. The waste water treatment plant is out of the scope of this study.

Wells were installed for cleaning of the transport pipes. These wells were $0.30 \mathrm{~m}$ in diameter and installed for each $100 \mathrm{~m}$ of pipe in the landfill. In total 82 wells were included each containing a polyvinylchloride pipe, HDPE bottom and polypropylene cap (Wavin 2009). The excavation and soil work for the wells were included in the estimated soil works and thus the diesel consumption is accounted for in the inventory.

\section{Leachate tank}

The leachate tank was constructed in reinforced concrete and had a diameter of $30 \mathrm{~m}$ and a height of 3 $\mathrm{m}$. The electronic installations included a breaker panel and estimated $100 \mathrm{~m}$ of cables and cable trays.

\section{Pumping station}

The station for pumping leachate from the landfill to the municipal waste water treatment system was constructed in concrete with 5\% reinforcement of steel (depth $=6 \mathrm{~m}$, width $=5 \mathrm{~m}$ and lenght $=6 \mathrm{~m})$. Materials for connecting pipes, fittings, valves and an aluminium ladder of $6 \mathrm{~m}$ were quantified. The pumping station was assumed to use two pumps of $74 \mathrm{~kg}$ and a hydraulic power of $1.29 \mathrm{~kW}$. Data about the pumps were provided by the company "Flygt" (Flygt 2012). The SCADA system for the pumping station was estimated to contain $28 \mathrm{~m}$ of cable tray and cables and one breaker panel. The breaker panel was not quantified due to lack of data about the size.

\section{Surface water collection/systems}

Ditches were established for the collection of surface water. The excavated soil from this was stored for other purposes at the landfill. Ponds for storing of collected surface water were not included. This 
kind of storage can be constructed in concrete and the water can be used for dust control during filling of the landfill.

\section{Groundwater monitoring wells}

Six groundwater monitoring wells were established; three upstream and three downstream of the landfill. Data for these wells were obtained from a study from the Danish utility company Copenhagen Energy (Godskesen 2011).

\section{Fence and gates}

A fence and gates were installed in order to avoid illegal dumping and other unwanted activities at the landfill site. Data about gates and fence were obtained from the Danish company Ishøj Hegn (Visti 2011). A fence $2 \mathrm{~m}$ high surrounded the site, placed at a distance of $65 \mathrm{~m}$ from the landfill. The fence surrounded also the receiving area at the entrance of the site, which was estimated to $40000 \mathrm{~m}^{2}$. The two combined gates were each $3 \mathrm{~m}$ wide and $2 \mathrm{~m}$ high. The total length of the fence was approximately $3100 \mathrm{~m}$.

\section{Receiving area}

Two weighbridges were installed in order to weigh all arriving and departing trucks. Data for the material composition of this was obtained from the Danish company Scanvægt (Scanvægt 2012). Weighbridges of $18 \mathrm{~m}$ times $3 \mathrm{~m}$ were used. The concrete parts were estimated to have a weight of 49 tonnes and the compact ring-torsion load cells were assumed to consist only of steel and have a total weight of $0.21 \mathrm{t}$.

Two buildings were placed in this area; one containing offices (200 $\mathrm{m}^{2}$ with two floors), the other building contains garages and truck wash of in total $300 \mathrm{~m}^{2}$. The detailed data for the buildings were obtained from the Swiss database Ecoinvent (Ecoinvent 2011), but presented in Table 2 only as area of buildings.

Asphalt roads were used in the receiving area and to the landfill cells. The asphalt road was estimated as twice the length of the sides of the landfill (in total $1094 \mathrm{~m}$ ). Gravel roads were used on the landfill body during the filling of the landfill. These were moved and changed as the cells were filled. A total of $1500 \mathrm{~m}$ of gravel roads were estimated.

An estimated number of 32 steel light stands were used to lighten the trafficked area. The electrical wiring was estimated to amount to $2800 \mathrm{~m}$ of electric cables. Cables for signals and signs were estimated to amount to $1000 \mathrm{~m}$.

No arrangements such as grates, bumps and washing facilities for wheels as suggested by Bagchi (1994) were included. The washing hall was the only facility for cleaning the trucks.

\section{Top-cover and gas collection}

When landfill cells are completed, the waste is levelled by a bulldozer and the gas collection system is installed. One vertical well (diameter of $0.600 \mathrm{~m}$ ) was drilled and equipped in the centre with a perforated HDPE gas extraction pipe (diameter of $0.160 \mathrm{~m}$ ), surrounded with gravel. One well was used per $2000 \mathrm{~m}^{2}$ of surface (or 5 wells per cell) for collecting the gas (see Figure 2). A HDPE 
membrane with a diameter of $10 \mathrm{~m}$ was installed around each well to limit atmospheric air to the well since the pumping of landfill gas creates a low pressure in the landfill. All wells were connected by HDPE pipes (diameter of $0.075 \mathrm{~m}$ ) to a pumping system and the landfill gas was collected for use in a gas motor at the site. The pumping system was placed in four forty-foot containers each of $6000 \mathrm{~kg}$ and with $9897 \mathrm{~kg}$ of equipment. Gas motors and generators were placed in four other containers each with a total weight of $25000 \mathrm{~kg}$. The top cover consisted of a layer of gravel $(0.5 \mathrm{~m})$ on top of the waste and a layer of soil $(0.8 \mathrm{~m})$ and finally the original top soil $(0.2 \mathrm{~m})$. A small flare of 2.3 tonnes of steel was installed at the site. Details on the flare were from the company Uniflare (Uniflare 2012).

In some countries synthetic top liners are prescribed. The material use for this can be estimated from the data on the synthetic liner specified for the bottom liner. This is also applicable for additional layers of soil or clay for the top cover.

\subsection{Soil balance}

Soil was excavated to prepare the area and to provide materials for soil embankments and top cover. Table 5 reveals that more soil was stored than later used. The surplus soil was assumed to stay on the site for additional landscaping. Two types of soil were excavated during the preparation of the site; top soil $(0-0.2 \mathrm{~m})$ and sub soil $(0.2-1 \mathrm{~m})$; these were kept separate and used for different purposes. The soil excavated from ditches was used as back-fill.

Embankments were constructed from soil excavated from the site. The amount is shown in Table 2, but does not contribute to the soil balance in Table 5, since the soils was used directly and not stored before use.

Daily cover of the waste with soil was not included in the quantification since this is a part of the daily landfill operation and thereby not a part of the construction of the landfill.

Table 5: Soil balance of the construction of a hill type landfill $\left(4\right.$ million $\mathrm{m}^{3}$ and $\left.300000 \mathrm{~m}^{2}\right)$. Positive numbers are tonnes of soil excavated and transported for temporary storage at the landfill site. Negative numbers are tonnes of soil taken from the storage.

\begin{tabular}{|l|r|}
\hline Description & Soil in temporary storage \\
\hline Unit & {$[\mathrm{t}]$} \\
\hline Preparing earthwork & 72000 \\
\hline Topsoil $(\mathrm{t}=0.2 \mathrm{~m})$ stripping and transport to deposit at site & 432000 \\
\hline Soil $(\mathrm{t}=0.6 \mathrm{~m})$ for top cover, stripping and transport to deposit at site & \\
\hline \multicolumn{2}{|}{$\mid \begin{array}{r}\text { Soil from site used for embankments and } \\
\text { thereby not counted in this balance }\end{array}$} \\
\hline Excavation of soil and establishment of embankments etc. & 3286 \\
\hline Surface water systems & -408000 \\
\hline Excavating intercepting ditches, $\mathrm{d}=1.0 \mathrm{~m}$ & $-\mathbf{- 7 2 0 0 0}$ \\
\hline Top cover and gas collection & $\mathbf{2 7 2 8 6}$ \\
\hline Soil cover $(\mathrm{t}=0.8 \mathrm{~m})$ built in from storage at site & \\
\hline Top soil $(\mathrm{t}=0.2 \mathrm{~m})$ built in from storage at site & \\
\hline Total amount in deposit & \\
\hline
\end{tabular}




\subsection{Life time of materials and components}

The estimated life times of the components above ground in the landfill are shown in Table 6 . These are used to calculate the need for maintenance and replacement of components. The time for operating the landfill is estimated to be 10 years and the aftercare period 30 years.

Table 6: Life time and thereby need for maintenance or change of components for a landfill of 4 million $\mathrm{m}^{3}$.

\begin{tabular}{|l|r|r|r|}
\hline \multicolumn{5}{|c|}{ Life time of landfill } \\
\hline Operation/filling & Total \\
\hline Component & 10 & After care & 40 \\
\hline & Estimated lifetime & Maintenance/Replacement & Period of time \\
\hline Asphalt & {$[$ Years] } & {$[$ Times] } & \\
\hline Weigh bridge & 10 & 0 & Operation/filling \\
\hline Buildings & 20 & 0 & Operation/filling \\
\hline Leachate tank & 20 & 0 & Operation/filling \\
\hline Pumps & 30 & 1 & Whole lifetime \\
\hline Fence and gates & 10 & 3 & Whole lifetime \\
\hline Gas motor & 10 & 3 & Whole lifetime \\
\hline Wells & 10 & 3 & Whole lifetime \\
\hline
\end{tabular}

\section{Results and discussion}

The results are presented in two parts: quantification of capital goods in terms of materials and energy used for the construction of the landfill and the environmental profile of the capital goods as modelled by environmental impact assessment.

\subsection{Capital goods (material and energy use) for construction of landfill}

Aggregated data per tonne of waste for the materials used to build a hill type landfill of 4 million $\mathrm{m}^{3}$ is presented in Table 7 and listed together with the results from Menard et al. (2004) and Ecobalance (1999). Some materials were reported only in this study. These were: cables and reinforcement steel as well as the small amounts of aluminium, copper (for pumps) and polypropylene.

In this study infiltration of rain to the landfill was allowed to shorten the period of aftercare while Ecobalance (1999) and Menard et al. (2004) use a full top cover to avoid infiltration of rain. Ecobalance (1999) reports a lower consumption of HDPE despite a top cover containing a HDPE liner and pipes. This could be due to the reported data are average numbers. Menard et al. (2004) included both geo-net and geo-membrane leading to a higher consumption of HDPE.

The use of concrete per tonne of waste was higher in this study than reported by Ecobalance (1999). Data from Ecobalance (1999) represented the average of 13 sites where 8 had no consumption of concrete and one had a high consumption due to a concrete road (Ecobalance 1999). This explains the low average value reported by Ecobalance (1999). In the present study the total diesel consumption per tonne of waste was 0.241 of diesel and Ecobalance (1999) reports 0.291 fuel per tonne of waste, while Menard et al. (2004) report 0.521 per tonne of waste. All studies included transportation to site and at site. Gravel and clay used in drainage layers and as geological barrier respectively were the materials used in the largest amounts. Ecobalance (1999) reports the use of gravel and both Ecobalance (1999) and Menard et al. (2004) report the use of sand. Limited access to clay could be 
the reason for Menard et al. (2004) reporting use of geosynthetic clay liner. Different design and use of material for the liner and leachate drainage system are the likely causes of these differences.

Parts of the landfill will be the same no matter the capacity and amount of waste landfilled. These parts constitute the "Basis" and include: receiving area with weighbridge, office buildings, monitoring wells, lighting, flare, roads and gates. The variable parts depend on the size of the landfill and these are: top cover, liner system, gas and leachate collection system, fence and all wells, pipes and tanks. The "Basis" contributes $16-40 \%$ of the total impacts on: Aquatic Eutrophication, Resources and the toxicity categories (See Figure 3). For most of the non-toxicity impact categories the "Basis" contributes approximately $10 \%$ of the total impacts (See Figure 3).

The use of materials is clearly defined by the design of the landfill. The design depends on regulations for protecting the ground water resource, for the length of the aftercare period and the final use of the site. A different liner system or top cover, thicker gravel/clay layers or different materials will change the total amounts of materials per tonne of waste. 
Table 7: Aggregated quantified amounts of materials used per ton of waste landfilled: this study and data reported by Menard et. al.(2004) and Ecobalance (1999).

\begin{tabular}{|c|c|c|c|c|}
\hline Materials & Unit & Ecobalance, 1999 & Menard et al., 2004 & This paper \\
\hline Aluminium & [kg/t of waste] & - & - & 5.84E-05 \\
\hline Asphalt & [kg/t of waste] & 0.09 & - & 0.12 \\
\hline Cables & {$[\mathrm{m} / \mathrm{t}$ of waste $]$} & - & - & $1.15 \mathrm{E}-03$ \\
\hline Clay & [kg/t of waste] & 133.00 & 0.03 & 82.27 \\
\hline Concrete & [kg/t of waste] & 0.09 & - & 0.44 \\
\hline Copper & [kg/t of waste] & - & - & $9.87 \mathrm{E}-06$ \\
\hline Diesel & [1/t of waste $]$ & 0.29 & 0.52 & 0.24 \\
\hline Geonet & [kg/t of waste] & - & 0.59 & - \\
\hline Geosynthetic clay liner & [kg/t of waste] & - & 0.43 & - \\
\hline Gravel & [kg/t of waste] & - & 105.33 & 180.03 \\
\hline HDPE & [kg/t of waste] & 0.18 & 0.86 & 0.23 \\
\hline $\mathrm{PP}$ & [kg/t of waste] & - & - & $4.02 \mathrm{E}-05$ \\
\hline $\mathrm{PVC}$ & {$[\mathrm{kg} / \mathrm{t}$ of waste $]$} & 0.01 & $8.10 \mathrm{E}-04$ & 0.01 \\
\hline Reinforcement steel & [kg/t of waste] & - & - & 0.05 \\
\hline Sand & [kg/t of waste] & 86.80 & 107.33 & - \\
\hline Soil & [kg/t of waste] & 172.90 & 22.33 & 168.92 \\
\hline Steel & {$[\mathrm{kg} / \mathrm{t}$ of waste $]$} & 0.02 & - & 0.09 \\
\hline External electricity & {$[\mathrm{MJ} / \mathrm{t}$ of waste] } & - & 426.67 & - \\
\hline External heat & {$[\mathrm{MJ} / \mathrm{t}$ of waste $]$} & - & 1301.67 & - \\
\hline Total capacity & [t of waste] & 12500000 & 600000 & 3500000 \\
\hline
\end{tabular}

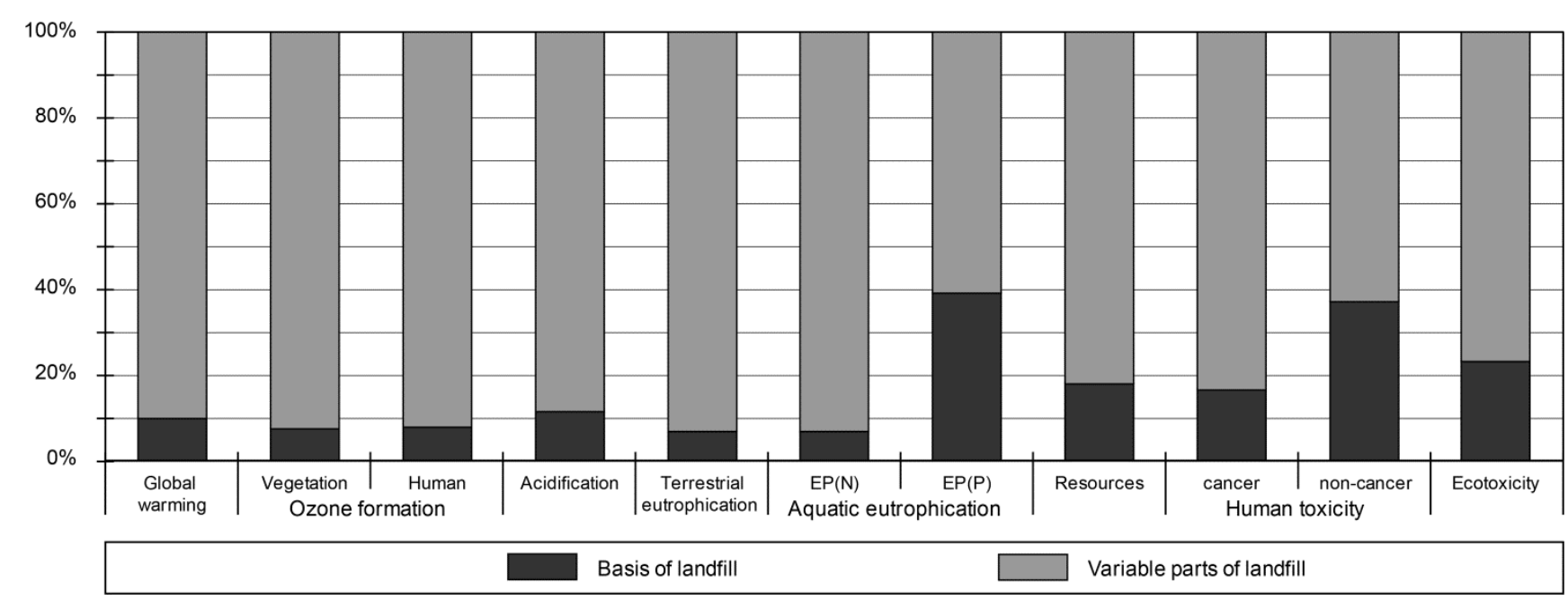

Figure 3: Contribution to EDIP impact categories (non-toxicity impact categories) and USEtox impact categories on Human Toxicity related to cancer and non-cancer and Ecotoxicity from the construction of the basis and the variable parts of a hill type landfill of 4 million $\mathrm{m}^{3}$. 


\subsection{Environmental impact assessment of capital goods use for construction of landfill}

The impacts related to the capital goods used for construction of a hill type landfill of 4 million $\mathrm{m}^{3}$ are presented in Figure 4. The potential impacts are given in milli Person Equivalents (mPE) per tonne of waste as "normalized impact potentials". The results are presented in this section for each of the impact categories. The impact on Ozone Depletion was not significant and is not shown.

\section{Global warming}

It is mainly the production of plastic for liner and pipes and gravel excavation that cause the impacts on Global Warming. Other contributors to impacts on Global Warming are the transportation of materials to the site and the use of machinery during construction.

\section{Ozone Formation (impact on vegetation and humans)}

The activities contributing the most to the Ozone Formation was the excavation and production of gravel and clay. The impacts from these materials do not include the transportation to site since this is counted separately.

\section{Acidification}

Use of machinery and thereby use of fuels for the excavation and preparation of clay and gravel gave the highest contribution to Acidification. Also the use of fuel at site contributes to the impact on Acidification.

\section{Terrestrial Eutrophication}

Transportation at the landfill site and the use of gravel gave the main impacts on the Terrestrial Eutrophication. A lot of energy is used for excavating the large amounts of gravel used in the construction of the landfill.

\section{Aquatic Eutrophication ( $N$ - and P-equivalents)}

The major impact on Aquatic Eutrophication was caused by the excavation and processing of gravel and the use of machinery at the landfill site. One of the main contributors to the impact category Aquatic Eutrophication expressed as Phosphorous equivalents was the office and garage/carwash buildings constructed at the site. The buildings contribute due to the resources used for the building materials but also the energy used during construction of the buildings. Another main contributor is the use of steel for e.g. gas management containers.

\section{Resource Depletion}

The main impact on Resource Depletion was caused by the use of steel, aluminium and copper but also by the excavation and preparation of gravel. The gravel has lower impacts per kg material compared to the metals but was used in a large quantity resulting in major contribution to the potential impact on Resource Depletion.

\section{Human Toxicity (Cancer/Non Cancer)}

The impacts on Human Toxicity were mainly caused by the production of steel. For the cancer related Human Toxicity it was the steel used for equipment for gas collection and gas motors, fence and gates and the reinforcement steel used in concrete constructions. For the non-cancer related Human Toxicity 
it was also the use of steel but also the office and garage/carwash buildings at the site. For both impact categories the use of gravel caused a high impact because of energy use for excavation and processing.

\section{Ecotoxicity}

The impacts on Ecotoxicity was caused by the use of steel for equipment used for gas management, fence and gates but also reinforcing steel used for concrete structures. The use of gravel also caused major impacts on this category due to energy used for excavation of the gravel at the mine.
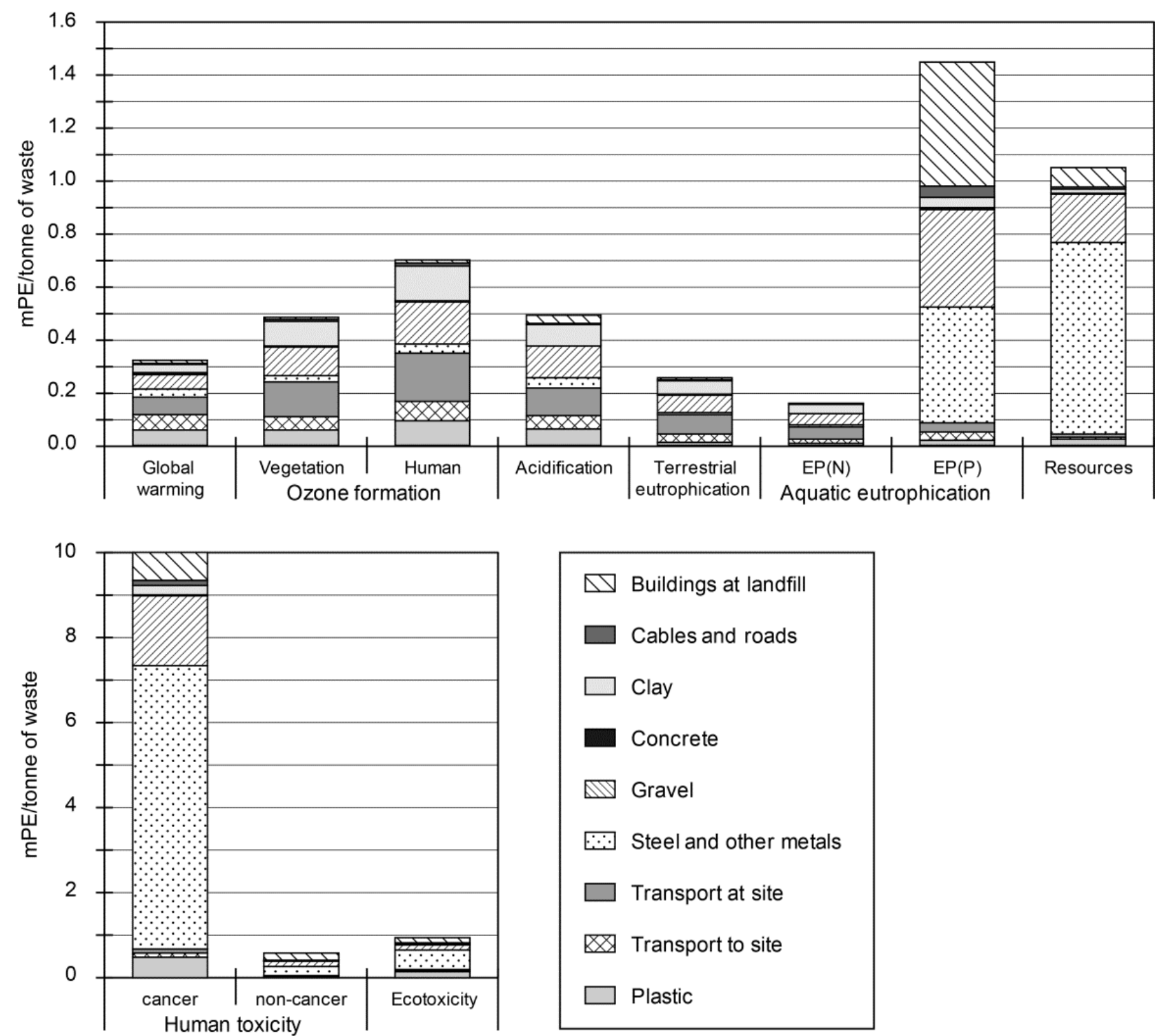

$\square$ Buildings at landfill
$\square$ Cables and roads
$\square$ Clay
Concrete
$\square$ Gravel
$\square$ Steel and other metals
$\square$ Transport at site
$\square$ Transport to site
$\square$ Plastic

Figure 4: Contribution to EDIP impact categories (non-toxicity impact categories) and USEtox impact categories on Human Toxicity related to cancer and non-cancer and Ecotoxicity from the construction of the assessed hill type landfill of 4 million $\mathrm{m}^{3}$. All units are in milli Person Equivalents per tonne of waste. EP(N): Emission Potential expressed as Nitrogen-equivalents and EP(P) in Phosphorous-equivalents.

\subsection{Waste types}

The capital goods used in construction depends on the waste landfilled. Materials for the gas collection system are only relevant when organic waste is part of the waste landfilled. Gas and gas collection will not be an issue in landfills with inert and non-organic waste. Materials used for 
construction of a leachate collection and drainage system will usually be relevant since handling of leachate is needed for most kinds of modern landfills.

The material consumption per tonne of waste highly depends on the height of the waste landfilled and the bulk density of the waste in situ. Municipal solid waste can be compacted to $0.7-1$ tonne per $\mathrm{m}^{3}$ (Christensen, 2011) though the compaction of the waste may depend on the scale of the landfill, since small sites often do not use heavy compactors but prefer lighter and more versatile machinery on site. Less waste in the landfill will mean higher impacts from the capital goods per tonne of waste. The data presented in Figure 4 are calculated for an average height of $10 \mathrm{~m}$, a maximum height of $20 \mathrm{~m}$ and with an average density of 0.85 tonnes per $\mathrm{m}^{3}$ corresponding to a total capacity of 3.5 million tons of waste (3 464410 t). The data can easily be adjusted to represent other depths or densities.

\subsection{Impacts per tonne of waste}

The total impacts per tonne of waste are presented in Figure 4. The materials used in large quantities contribute the most to the potential impacts. Gravel and clay as well as steel contribute to all the impact categories. The impacts caused by transportation of materials and use of machinery at site are also significant especially for the Ozone Formation impacts on vegetation and human health, Acidification and Terrestrial Eutrophication. The potential impact on Global Warming is $0.32 \mathrm{mPE}$ per tonne of waste, see Table 8. Manfredi et al. (2010) reported a potential impact of $4 \mathrm{mPE}$ per tonne of waste from the operation of a landfill with low organic waste. For a conventional landfill with energy recovery a contribution to Global Warming was reported of (minus) $-21 \mathrm{mPE} / \mathrm{t}$ wet waste (Manfredi and Christensen 2009). This indicates that with respect to Global Warming the contribution of capital goods to the overall environmental profile of a landfill is small to insignificant (1.5 - 8\%). The impact on Resource Depletion was not assessed by Manfredi et al. (2010) or Manfredi and Christensen (2009) but is considered to be significant for the capital goods.

Table 8: Potential impact on Global warming from the capital goods and references from literature.

\begin{tabular}{|l|l|l|}
\hline Reference & $\begin{array}{l}\text { Potential impact on Global } \\
\text { Warming from Capital goods }\end{array}$ & $\begin{array}{l}\text { Potential impact on Global } \\
\text { Warming from operation of } \\
\text { landfill }\end{array}$ \\
\hline & {$[\mathrm{mPE} /$ tonne of waste $]$} & {$[\mathrm{mPE} /$ tonne of waste $]$} \\
\hline This paper & 0.32 & \\
\hline Manfredi et al. 2010 & & 4 \\
\hline Manfredi and Christensen 2009 & & -21 \\
\hline
\end{tabular}

\section{Sensitivity of Results}

Transportation distances used for the quantification of diesel are estimated to be relatively short (15$50 \mathrm{~km}$ ). The impact on Global Warming constitutes $18 \%$ from the transportation of goods to the landfill. Changing the distance of the transporting the HDPE membrane from $25 \mathrm{~km}$ to $1000 \mathrm{~km}$ increase total the impact on Global Warming with only $0.5 \%$. Changing the transportation distance of gravel from $15 \mathrm{~km}$ to $100 \mathrm{~km}$ increases the impact on Global Warming with $39 \%$. 
The potential environmental impacts depend on choice of materials and the design of the landfill. As an example a geo-membrane of HDPE covering the whole landfill to avoid infiltration of water would change the environmental impact potentials by an increase of $40 \%$.

The aftercare period of landfills is specified to be of minimum 30 years in both the European and the North American landfill regulations. Therefore an aftercare period of 30 years was chosen for this study. Kjeldsen et al. (2002) describe a need for longer aftercare period due to non-stabilised conditions in the landfills. The potential environmental impacts would be higher from this study, if a longer aftercare period was considered. The higher impacts would be caused by the use of steel in the capital goods (fence, gates and gas motor) needed for the longer period of time.

The result of the environmental impact assessment depends on the processes chosen from the available database. If processes with higher or lower impacts were used, the total impacts would differ. The processes used for the modelling are shown in Table 9. In this way the reader will be able either to do the same modelling or to change some of the processes if more relevant data are available. 
Table 9: Material processes used in modelling of the environmental profile of the capital goods.

\begin{tabular}{|c|c|c|c|c|}
\hline Material & Type & Stage & Geographical area & Reference \\
\hline Aluminium & Primary & at plant & Europe & Ecoinvent 2011 \\
\hline Cable & PVC & at plant & Europe & Thiesen 2012 \\
\hline Clay & Unspecified & at mine & Switzerland & Ecoinvent 2011 \\
\hline Concrete & Normal & at plant & Switzerland & Ecoinvent 2011 \\
\hline Copper & Primary & at refinery & Europe & Ecoinvent 2011 \\
\hline Gravel & Round & at mine & Switzerland & Ecoinvent 2011 \\
\hline Lorry & EURO5/lorry 16-32t & operation & Europe & Ecoinvent 2011 \\
\hline Lorry & EURO3/lorry $>32 t$ & operation & Europe & Ecoinvent 2011 \\
\hline Polyethylene HDPE & Granulate & at plant & Europe & Ecoinvent 2011 \\
\hline Polypropylene PP & Granulate & at plant & Europe & Ecoinvent 2011 \\
\hline Polyvinylchloride PVC & Unspecified & at regional storage & Europe & Ecoinvent 2011 \\
\hline Reinforcing steel & Unspecified & at plant & Europe & Ecoinvent 2011 \\
\hline Roads & Company & internal & Switzerland & Ecoinvent 2011 \\
\hline Steel & Low-alloyed & at plant & Europe & Ecoinvent 2011 \\
\hline \multicolumn{5}{|l|}{ Cables } \\
\hline Copper & Primary & At refinery & World & Ecoinvent 2012 \\
\hline Polyvinylchloride PVC & Unspecified & at regional storage & Europe & Ecoinvent 2011 \\
\hline Limestone & Milled and packed & At plant & Switzerland & Ecoinvent 2012 \\
\hline Dimethyl p-phthalate & - & - & Switzerland & ETH-ESU 1996 \\
\hline Electricity & High voltage, UCTE & at grid & Europe & Ecoinvent 2012 \\
\hline
\end{tabular}

\section{Conclusions}

Capital goods in terms of materials and energy used for constructing an engineered landfill of 4 million $\mathrm{m}^{3}$ were quantified and presented. The largest amounts of materials used were clay and gravel followed by concrete and plastic for liners and pipes. Expressed per tonne of waste the amounts of materials and energy used were of the same order as data provided by two earlier studies. Differences were apparent with respect to the amount of clay and gravel used, but likely this can be ascribed to different design of the bottom liner and leachate drainage system. The data provided in the current study is very detailed and allows the reader to make inventories for other landfill designs. Capital goods as materials and energy used per tonne of waste are likely to depend on the requirements for liners, the depth of the landfill, the bulk density of the waste after landfilling and transportation. These factors are believed to be of much more importance that the uncertainty of the individual numbers provided in the inventory table based on a hypothetical hill type landfill. Except for the receiving area with buildings and weighbridge, most use of materials and energy for construction of a landfill are linear with the size of the landfill.

The materials used in the largest amounts (clay and gravel) were also the materials contributing most to the environmental profile of the capital goods expressed as impact categories (Global Warming, Ozone Formation (vegetation and human), Acidification, Terrestrial and Aquatic Eutrophication, Resource Depletion and Human Toxicity (Cancer)). Plastics (liner, pipes) and metals (reinforcement, pumps, fence and gates) were used in smaller amounts but have higher environmental impacts from their production and thus also showed significant contribution to all impact categories. Plastic contributed mostly to Global Warming, Ozone Formation (vegetation and human), Acidification, Human Toxicity (Cancer) and Ecotoxicity). The steel contributed mostly to Aquatic Eutrophication 
(P-equivalents), Resource Depletion, Human Toxicity (Cancer and non-cancer related) and Ecotoxicity.

The transport of materials to the landfill and their transport and handling at the landfill contributed significantly to many impact categories in terms of diesel combustion (Global Warming, Ozone Formation (human), Acidification, Terrestrial and Aquatic Eutrophication (N-equivalents)).

The potential impact of the capital goods on Global warming was $0.32 \mathrm{mPE} / \mathrm{t}$ of waste which is low to insignificant compared to the impact potential of $4 \mathrm{mPE} / \mathrm{t}$ waste from the operation of a landfill with low organic waste reported by Manfredi et al. (2010) and to $-21 \mathrm{mPE} / \mathrm{t}$ of wet waste for a conventional landfill with energy recovery (Manfredi and Christensen 2009). The impact of the capital goods on Resource Depletion, however, is significant due to the use of gravel and steel.

\section{Acknowledgement}

The authors would like to thank the graduate school Residual Resource Research (3R) at the Technical University of Denmark for partly financing the scholarship for this PhD research.

\section{References}

Bagchi A. (1994) Design, construction and monitoring of landfills, Second edition, Wisconsin Department of Natural Resources, John Wiley \& Sons, Ltd, USA

Camobreco V, Ham R, Barlaz M, Repa E, Felker M, Rousseau C and Rathle J (1999) Life-cycle inventory of a modern municipal solid waste landfill, Waste Management and Research, Volume 17, Issue 6, pages 394-408

Caterpillar Inc. (2009) Caterpillar Performance Handbook, Peroria, Illinois, U.S.A

Christensen T H (2011) Solid Waste Technology \& Management. Volume 1 \& 2. (Ed T. H. Christensen), John Wiley \& Sons, Ltd, Chichester, United Kingdom.

Cleary J (2009) Life cycle assessments of municipal solid waste management systems: A comparative analysis of selected peer-reviewed literature. Environment International, Volume 35, Issue 8, pp. $1256-1266$

Ecobalance (1999) Life Cycle Inventory of a Modern Municipal Solid Waste Landfill, Prepared for: Environmental Research and Education Foundation by Ecobalance Inc 7101 Wisconsin Ave, Suite 700 Bethesda, MD 20814, USA

Ecoinvent (2011) Swiss Centre for Life Cycle Inventories, Ecoinvent, V2.2, c/o Empa/Technology \& Society Lab (TSL), Lerchenfeldstrasse 5, 9014 St-Gallen, Switzerland

ETH-ESU (1996) Eidgenössische Technische Hochschule, Gruppe Energie-Stoffe-Umwelt, The Energy-Materials-Environment Group at the Swiss Federal Institute of Technology, Zurich, Switzerland 
Flygt (2012) Environmental Product Declaration, Flygt 3085.183, ITT Water \& Wastewater AB, SE-174 87 Sundbyberg, Sweden. http://gryphon.environdec.com/data/files/6/7230/epde62.pdf (accessed 30 May 2012)

Frischknecht R., Althaus H-J, Bauer C, Doka G, Heck T, Jungbluth N, Kellenberger D, Nemecek T (2007) The Environmental Relevance of Capital Goods in Life Cycle Assessments of Products and Services. International Journal of Life Cycle Assessment, 12, Special Issue 1, pp. 7-17.

Godskesen B (2011) Personal communication with Berit Godskesen about establishment of wells including pumps. Copenhagen Energy, Oerestads Boulevard 35, DK-2300 Copenhagen S, Denmark

Kjeldsen P, Barlaz M A, Rooker A P, Baun A, Ledin A, \& Christensen T H (2002): Present and LongTerm Composition of MSW Landfill Leachate: A Review, Critical Reviews in Environmental Science and Technology, 32:4, 297-336

Laurent A, Olsen S I and Hauschild M Z (2011a) Normalization in EDIP97 and EDIP2003: updated European inventory for 2004 and guidance towards a consistent use in practice. International Journal of Life Cycle Assessment, 16:401-409

Laurent A, Lautier A, Rosenbaum R K, Olsen S I, Hauschild M Z (2011b) Normalization references for Europe and North America for application with USEtox ${ }^{\mathrm{TM}}$ characterization factors. International Journal of Life Cycle Assessment 16(8).

Manfredi S and Christensen T H (2009) Environmental assessment of solid waste landfilling technologies by means of LCA-modeling, Waste Management 29: 32-43

Manfredi S, Christensen T H, Scharff H and Jacobs J. (2010) Environmental assessment of loworganic waste landfill scenarios by means of life-cycle assessment, Waste Management \& Research, 28: $130-140$

Ménard J-F, Lesage P, Deschênes L and Samson R (2004) Comparative Life Cycle Assessment of Two Landfill Technologies for the Treatment of Municipal Solid Waste, International Journal of LCA 9 (6) $371-378$.

Thiesen J, Director QHSE, Personal communication, NKT cables group a/s, Toftegaardsvej 25, DK4550 Asnaes, Denmark

PRé, Product Ecology consultants (2011) Simapro software version 7.2, The Netherlands, www.presustainability.com/.

ROAD-RES (2005) Life cycle assessment tool, Road construction and residue disposal, Technical University of Denmark, Lyngby, Denmark

Scanvægt (2012) Brochure: Weighbridge 7800, Functional design and fast installation, Scanvægt Nordic A/S, Johann Gutenbergs Vej 5-9 8200 Aarhus N Denmark, www.scanvaegt.dk 
Stripple H (2001) Life Cycle Assessment of Road, A Pilot Study for Inventory Analysis, Second Revised Edition, The Swedish Environmental Research Institute, Gothenburg, Sweden

Uniflare (2012) Uniflare, Glabal Environmental Technology, Unit 19, Runway Farm Technical Park, Honiley Road, Kenilworth, Warwickshire, CV8 1NQ, England, http://www.uniflare.co.uk/

USEtox (2009) USEtox model developed by the Task Force on Toxic Impacts under the UNEPSETAC Life Cycle Initiative. http://www.usetox.org/

Visti L (2011) Personal communication with Lars Visti from Ishøj Hegn A/S, Industrivangen 2-6, 2635 Ishøj. http://www.ishoj-hegn.dk/

Wavin (2009) Brochure: Brønde, Afløbssystem, Nordisk Wavin A/S, Wavinvej 1, DK-8450 Hammel, Denmark, www.wavin.dk (accessed 30 May 2012)

Wenzel H, Hauschild M Z and Alting L (1997) Environmental Assessment of Products. Methodology, tools and case studies in product development, vol. 1. Chapman \& Hall, 2-6 Boundary row, London, UK 